\title{
Maintenance of Insulin Release from Pancreatic Islets Stored in the Cold for up to 5 Weeks
}

\author{
Barbara J. Frankel, Erik Gylfe, Bo Hellman, and Lars-Åke Idahl \\ From the Department of Histology, University of Umeå, \\ S-901 87 Umeå, Sweden
}

\begin{abstract}
A в S T R A C T Insulin content and release were measured from hand-dissected pancreatic islets from noninbred $a b / o b$ mice after 1-5 wk storage in tissue culture medium 199 at various temperatures and glucose concentrations.
\end{abstract}

After storage of islets for $1 \mathrm{wk}$ at $37^{\circ}, 22^{\circ}$, or $8^{\circ} \mathrm{C}$ in $18 \mathrm{mM}$ glucose medium and preincubation with $1 \mathrm{mM}$ glucose, glucose-stimulated insulin release during the subsequent incubation was only $20-35 \%$ of that of fresh islets. The addition of a $4-\mathrm{h}$ period at $37^{\circ} \mathrm{C}$ with $18 \mathrm{mM}$ glucose between the cold storage and perincubation restored glucose-stimulated insulin release from $8^{\circ} \mathrm{C}$ stored islets to fresh-islet levels. Release throughout the 1-18 $\mathrm{mM}$ glucose range was strikingly parallel to that of fresh islets. Exposure of fresh islets to the same 4-h period increased basal release but did not affect maximal release.

When islets were stored at $8^{\circ} \mathrm{C}$ with $18 \mathrm{mM}$ glucose for more than $1 \mathrm{wk}$, a short period at $37^{\circ} \mathrm{C}$ every week was necessary for maintenance of release. After $5 \mathrm{wk}$ of this procedure, glucose-stimulated insulin release was one-third that of fresh islets, or similar to that of islets stored for only $1 \mathrm{wk}$ at $37^{\circ} \mathrm{C}$. Storage at $8^{\circ} \mathrm{C}$ for $1 \mathrm{wk}$ with $3 \mathrm{mM}$ glucose, or continuously for 3 or $5 \mathrm{wk}$ with $18 \mathrm{mM}$ glucose, maintained islet insulin content, whereas release was lost.

Thus, glucose-stimulated insulin release is best maintained by storage of pancreatic islets in tissue culture medium with a high concentration of glucose at $8^{\circ} \mathrm{C}$ with short weekly periods at $37^{\circ} \mathrm{C}$.

This work was presented in part at the 11th Annual Meeting of the Scandinavian Society for the Study of Diabetes, Bergen, Norway, 5 June 1975, and at the 11th Annual Meeting of the European Association for the Study of Diabetes, Munich, W. Germany, 5 Sept. 1975.

Received for publication 23 June 1975 and in revised form 2 September 1975.

\section{INTRODUCTION}

Transplantation of pancreatic islet tissue may become an important treatment of diabetes. Implantation of islets, rather than whole pancreases, is surgically much simpler and less hazardous. In vitro preservation of functionally intact islets is of great importance to allow accumulation of enough islet material for transplantation.

Culture of islets at $37^{\circ} \mathrm{C}$ has been shown to result in a decreased ability to release insulin in response to glucose stimulation $(1,2)$. The use of low temperature in the preservation of kidneys (3), as well as other tissues (4-6), for transplantation has been extensively studied and found to maintain tissue function for a longer time than storage at warmer temperatures. Low temperature offers the further advantage of inhibiting fibroblast growth, which can be a problem when pancreatic islets are cultured at $37^{\circ} \mathrm{C}$ (7). Studies with mouse fibroblasts (8) have also indicated that storage at low temperatures allows longer survival than storage at $37^{\circ} \mathrm{C}$, and that survival at $4^{\circ} \mathrm{C}$ can be prolonged even more if the cells are allowed a few hours at $37^{\circ} \mathrm{C}$ every 5-8 days. We know of only one study (9) using cold storage for isolated islets: Knight et al. showed gross impairment of insulin secretion from isolated rat islets after only 3 days in Hanks' solution at $4^{\circ} \mathrm{C}$.

Using $\beta$-cell-rich islets, hand-dissected from noninbred $o b / o b$ mice, we present data on how glucose-stimulated insulin release can be maintained for at least $5 \mathrm{wk}$ by storage with a high concentration of glucose at $8^{\circ} \mathrm{C}$, interrupted by short periods at $37^{\circ} \mathrm{C}$.

\section{METHODS}

Chemicals and media. Reagents of analytical grade and distilled, deionized water were used throughout. HEPES ( $N$-2-hydroxyethyl-piperazine- $N^{\prime}$-2-ethane sulfonic acid) and bovine serum albumin (fraction V) were obtained from Sigma Chemical Co., St. Louis, Mo. Tissue culture medium 
199 (TCM 199, 10X concentration; Salk et al., ref. 10) was obtained from National Bacteriological Laboratories, Stockholm, Sweden, and benzylpenicillin was purchased from AB Kabi, Stockholm, Sweden. ${ }^{125}$ I-labeled insulin was from Farbwerke Hoechst AG. Crystalline mouse insulin was prepared by Novo A/S, Copenhagen, Denmark.

The basal medium in all dissections, storages, and incubations consisted of a modified TCM 199 with Hanks' salts, lacking glucose and phenol red, and buffered with $25 \mathrm{mM}$ HEPES. Bovine serum albumin (1 $\mathrm{mg} / \mathrm{ml})$ was added. The medium was sterilized by filtration through a Millex filter unit $(0.22 \mu \mathrm{m}$; Millipore S.A., Buc, France) and then kept overnight at $37^{\circ} \mathrm{C}$. Benzylpenicillin (50 $\mu \mathrm{g} /$ $\mathrm{ml}$ ) was then added, and the medium was adjusted to $\mathrm{pH}$ $7.35\left(37^{\circ} \mathrm{C}\right)$ with $\mathrm{NaOH}$. The $\mathrm{pH}$ of the solution stayed within 7.4 \pm 0.1 throughout the entire culture period. Glucose was added as noted in the tables and figure, and the medium was sterilized again just before use.

Animals and isolation of islets. Adult (8-9-mo-old) male, obese-hyperglycemic mice (gene symbol $o b / o b$ ) were taken from a local colony (11). After fasting overnight, the animals were killed by decapitation under ether anesthesia. Fresh pancreatic islets were microdissected (12) from the pancreases in basal medium containing $1 \mathrm{mM}$ glucose at room temperature.

Storage and incubation of islets. Isolated islets were transferred to sterile plastic Petri dishes (Heger Plastics $\mathrm{AB}$, Stallarholmen, Sweden) with a diameter of $5 \mathrm{~cm}$. Each dish contained two islets in $4 \mathrm{ml}$ of the basal medium supplemented with 3 or $18 \mathrm{mM}$ glucose. The dishes were stored in humidified air for 1,3 , or 5 wk at $8^{\circ}, 22^{\circ}$, or $37^{\circ} \mathrm{C}$.

Incubation of stored islets. The stored islets were either directly rinsed and preincubated for $2 \mathrm{~h}$ (Table I) at $37^{\circ} \mathrm{C}$ in $1 \mathrm{ml}$ medium containing $1 \mathrm{mM}$ glucose or were subjected to a 4 -h period at $37^{\circ} \mathrm{C}$ in $1 \mathrm{ml}, 18 \mathrm{mM}$ glucose medium ("recovery" period) before rinsing and preincubation (Tables II-IV, Fig. 1). After preincubation, the islets were rinsed and incubated for $1 \mathrm{~h}$ in $300 \mu \mathrm{l}$ basal medium supplemented with $1-18 \mathrm{mM}$ glucose, as noted in the tables and figure. In one series of experiments (Table IV), islets stored at $8^{\circ} \mathrm{C}$ were subjected to a weekly recovery period, preincubation, and incubation scheme for 5 consecutive wk.

Weighing of islets and assay of insulin. After incubation, the islets were placed on aluminum foil and as much contaminating fluid as possible was quickly removed with the aid of a micropipette. Islets were then freeze-dried overnight at $-40^{\circ} \mathrm{C}, 0.1 \mathrm{~Pa}(\cong 0.001 \mathrm{~mm} \mathrm{Hg})$, and weighed on a quartz fiber balance (13). Islets used for determination of insulin content were then subjected to ultrasonic disintegration in $1 \mathrm{mM} \mathrm{HCl}$ (Sonifier B-12, Branson Sonic Power, Co., Danbury, Conn., equipped with a microtip and run at a meter reading of $50 \mathrm{~W}$ ). Insulin in islet extracts and media was assayed radioimmunologically with crystalline mouse insulin as a standard.

Presentation of results. Insulin values are expressed per microgram dry weight of islet. Statistical significances were calculated from the mean difference between incubations with the two-tailed Student's $t$ test. Symbols in the tables indicate statistical significance of difference between paired incubations in 1 and $18 \mathrm{mM}$ glucose media during incubation as measured by paired $t$ test.

\section{RESULTS}

After storage of pancreatic islets for 1 wk at different temperatures with $18 \mathrm{mM}$ glucose, the time required to reach basal insulin release was studied during preincubation with $1 \mathrm{mM}$ glucose at $37^{\circ} \mathrm{C}$ (Table I). Insulin release from islets stored at $37^{\circ} \mathrm{C}$ fell to basal levels within $30 \mathrm{~min}$, whereas release from islets stored at $22^{\circ}$ or $8^{\circ} \mathrm{C}$ was greater and required $60 \mathrm{~min}$ to reach base line. When glucose-stimulated insulin release was

TABLE I

Insulin Release from Islets Stored 1 wk with $18 \mathrm{mM}$ Glucose

\begin{tabular}{|c|c|c|c|c|c|c|c|}
\hline \multirow[b]{3}{*}{$\begin{array}{c}\text { Storage } \\
\text { temperature }\end{array}$} & \multicolumn{7}{|c|}{ Insulin release* } \\
\hline & \multicolumn{4}{|c|}{ Preincubation $\ddagger$} & \multicolumn{3}{|c|}{ Incubation } \\
\hline & $\begin{array}{c}1 \\
30 \mathrm{~min}\end{array}$ & $\begin{array}{c}2 \\
30 \mathrm{~min}\end{array}$ & $\begin{array}{c}3 \\
30 \mathrm{~min}\end{array}$ & $\begin{array}{c}4 \\
30 \mathrm{~min}\end{array}$ & $\begin{array}{l}1 \mathrm{mM} \\
60 \mathrm{~min}\end{array}$ & $\begin{array}{l}18 \mathrm{mM} \\
60 \mathrm{~min}\end{array}$ & $\begin{array}{l}\text { Difference } \\
60 \mathrm{~min}\end{array}$ \\
\hline${ }^{\circ} \mathrm{C}$ & \multicolumn{7}{|c|}{$n g / \mu g d r y w t / h$} \\
\hline 37 & $\begin{array}{c}0.45 \pm 0.08 \\
(12)\end{array}$ & $\begin{array}{c}0.21 \pm 0.04 \\
\text { (11) }\end{array}$ & $\begin{array}{c}0.24 \pm 0.04 \\
(12)\end{array}$ & $\begin{array}{c}0.21 \pm 0.04 \\
\quad(12)\end{array}$ & $\begin{array}{c}0.29 \pm 0.09 \\
(6)\end{array}$ & $\begin{array}{c}1.48 \pm 0.44 \\
(6)\end{array}$ & $\begin{array}{c}1.18 \pm 0.49 \\
(6)\end{array}$ \\
\hline 22 & $\begin{array}{c}2.76 \pm 0.84 \\
(8)\end{array}$ & $\begin{array}{c}0.68 \pm 0.16 \\
(8)\end{array}$ & $\begin{array}{c}0.34 \pm 0.08 \\
(8)\end{array}$ & $\begin{array}{c}0.31 \pm 0.07 \\
(6)\end{array}$ & $\begin{array}{c}0.21 \pm 0.07 \\
(4)\end{array}$ & $\begin{array}{c}0.87 \pm 0.24 \\
(4)\end{array}$ & $\begin{array}{c}0.66 \pm 0.208 \\
(4)\end{array}$ \\
\hline 8 & $\begin{array}{c}1.25 \pm 0.20 \\
(14)\end{array}$ & $\begin{array}{c}0.41 \pm 0.08 \\
(13)\end{array}$ & $\begin{array}{c}0.27 \pm 0.06 \\
\quad(14)\end{array}$ & $\begin{array}{c}0.29 \pm 0.06 \\
(14)\end{array}$ & $\begin{array}{c}0.27 \pm 0.10 \\
(8)\end{array}$ & $\begin{array}{c}1.05 \pm 0.22 \\
(8)\end{array}$ & $\begin{array}{c}0.78 \pm 0.21 \| \\
(8)\end{array}$ \\
\hline $\begin{array}{l}\text { Fresh } \\
\quad \text { islets** }\end{array}$ & & & & & $\begin{array}{c}0.75 \pm 0.15 \\
\quad(11)\end{array}$ & $\begin{array}{c}4.09 \pm 0.77 \\
(11)\end{array}$ & $\begin{array}{l}3.34 \pm 0.78 \pi \\
\text { (11) }\end{array}$ \\
\hline
\end{tabular}

* Mean $\pm \mathrm{SEM}$ for the number of experiments listed in parentheses.

$\ddagger 2$-h preincubation divided into four 30 -min periods.

$\& P<0.05$.

$\| P<0.01$.

I $P<0.005$.

** Unstored islets were also preincubated for $2 \mathrm{~h}$, but insulin release was not measured. 
TABLE II

Insulin Release from Islets Stored 1 wk and then Allowed a 4-h "Recovery" Period

\begin{tabular}{|c|c|c|c|c|}
\hline \multirow{2}{*}{$\begin{array}{l}\text { Storage } \\
\text { temperature }\end{array}$} & \multirow{2}{*}{$\begin{array}{c}\text { Glucose } \\
\text { concen- } \\
\text { tration } \\
\text { in storage } \\
\text { medium }\end{array}$} & \multicolumn{3}{|c|}{ Insulin release during incubation* } \\
\hline & & $1 \mathrm{mM}$ & $18 \mathrm{mM}$ & Difference \\
\hline${ }^{\circ} \mathrm{C}$ & $m M$ & \multicolumn{3}{|c|}{$n g / \mu g d r y w t / h$} \\
\hline 37 & 18 & $\begin{array}{c}0.20 \pm 0.05 \\
(7)\end{array}$ & $\begin{array}{c}1.53 \pm 0.37 \\
(7)\end{array}$ & $\begin{array}{c}1.33 \pm 0.37 \ddagger \\
(7)\end{array}$ \\
\hline 22 & 18 & $\begin{array}{c}0.72 \pm 0.11 \\
(8)\end{array}$ & $\begin{array}{c}3.27 \pm 0.57 \\
(8)\end{array}$ & $\begin{array}{c}2.55 \pm 0.48 \S \\
(8)\end{array}$ \\
\hline 8 & 18 & $\begin{array}{c}0.59 \pm 0.09 \\
(9)\end{array}$ & $\begin{array}{c}5.20 \pm 1.26 \\
(9)\end{array}$ & $\begin{array}{c}4.61 \pm 1.208 \\
(9)\end{array}$ \\
\hline 37 & 3 & $\begin{array}{c}0.22 \pm 0.03 \\
(12)\end{array}$ & $\begin{array}{c}0.41 \pm 0.04 \\
(12)\end{array}$ & $\begin{array}{c}0.18 \pm 0.04 \| \\
\text { (12) }\end{array}$ \\
\hline 8 & 3 & $\begin{array}{c}0.46 \pm 0.08 \\
\quad(12)\end{array}$ & $\begin{array}{c}0.57 \pm 0.11 \\
\quad(12)\end{array}$ & $\begin{array}{c}0.10 \pm 0.08 \\
\quad(12)\end{array}$ \\
\hline $\begin{array}{l}\text { Fresh } \\
\quad \text { islets } \llbracket\end{array}$ & & $\begin{array}{c}1.70 \pm 0.31 \\
(10)\end{array}$ & $\begin{array}{c}6.72 \pm 1.14 \\
(10)\end{array}$ & $\begin{array}{c}5.02 \pm 1.328 \\
\quad(10)\end{array}$ \\
\hline
\end{tabular}

* Mean \pm SEM for the number of experiments listed in parentheses. $\ddagger P<0.02$.

$8 P<0.005$.

$\| P<0.001$.

I Unstored islets subjected to identical recovery, preincubation, and incubation periods.

measured after a total of $120 \mathrm{~min}$ of preincubation, insulin release was not significantly different among the $37^{\circ}$-, $22^{\circ}$-, or $8^{\circ} \mathrm{C}$-stored islets, although the response was only $20-35 \%$ of that from fresh islets.

The stored islets were given a 4-h recovery period at $37^{\circ} \mathrm{C}$ with $18 \mathrm{mM}$ glucose before preincubation and incubation (Table II). Islets stored for 1 wk at $8^{\circ} \mathrm{C}$ responded significantly better to glucose stimulation than islets stored at $37^{\circ} \mathrm{C}(P<0.05)$. The insulin response of the islets stored at $8^{\circ} \mathrm{C}$ was equal to that of fresh islets subjected to the same 4-h period. On the contrary, islets stored with only $3 \mathrm{mM}$ glucose at $37^{\circ} \mathrm{C}$ showed drastically reduced insulin responses to glucose.

The dose-response relationship of glucose-stimulated insulin release was measured in islets stored for $1 \mathrm{wk}$ at $8^{\circ} \mathrm{C}$ and in fresh islets exposed to a similar 4-h period at $37^{\circ} \mathrm{C}$ with $18 \mathrm{mM}$ glucose (Fig. 1). The sigmoidal dose-response relationship for fresh islets, as described by Buitrago et al. (1), is included for comparison. The dose-response curve for islets stored for $1 \mathrm{wk}$ at $8^{\circ} \mathrm{C}$ in $18 \mathrm{mM}$ glucose medium, and then allowed to "recover" for $4 \mathrm{~h}$ closely paralleled that of the fresh islets. Exposure of fresh islets to the 4-h period at $37^{\circ} \mathrm{C}$ in $18 \mathrm{mM}$ glucose medium before preincubation significantly increased the insulin release at the lower concentrations of glucose, but did not significantly change maximal release.

Regardless of the glucose concentration, storage for 1 wk at $22^{\circ}$ or $8^{\circ} \mathrm{C}$ was associated with little insulin release into the storage medium and with no decrease of islet insulin content as compared to fresh islets (Table III). In contrast, storage at $37^{\circ} \mathrm{C}$ with $18 \mathrm{mM}$ glucose caused a substantial release into the medium (equal to the entire content of fresh islets) and only a $30 \%$ fall in islet content, indicating that biosynthesis had occurred. When the islets were stored at $37^{\circ} \mathrm{C}$ with $3 \mathrm{mM}$ glucose, there was much less release than into the highglucose medium, but an even greater $(50 \%)$ fall of islet content of insulin.

The insulin responses to glucose after storage for up to $5 \mathrm{wk}$ at $8^{\circ} \mathrm{C}$ in $18 \mathrm{mM}$ glucose medium with or without weekly "recovery," preincubation, and incubation periods at $37^{\circ} \mathrm{C}$ were studied (Table IV). Insulin release into the storage medium decreased during the 5 wk and was similar from islets incubated weekly and those stored continuously in the cold. The islets incubated at $37^{\circ} \mathrm{C}$ weekly still responded to glucose stimulation after $5 \mathrm{wk}$, although the response was only about one-third that of fresh islets. In contrast, islets stored continuously at $8^{\circ} \mathrm{C}$ for 3 or 5 wk showed no response to glucose stimulation. Storage for $5 \mathrm{wk}$ at $8^{\circ} \mathrm{C}$, (with or

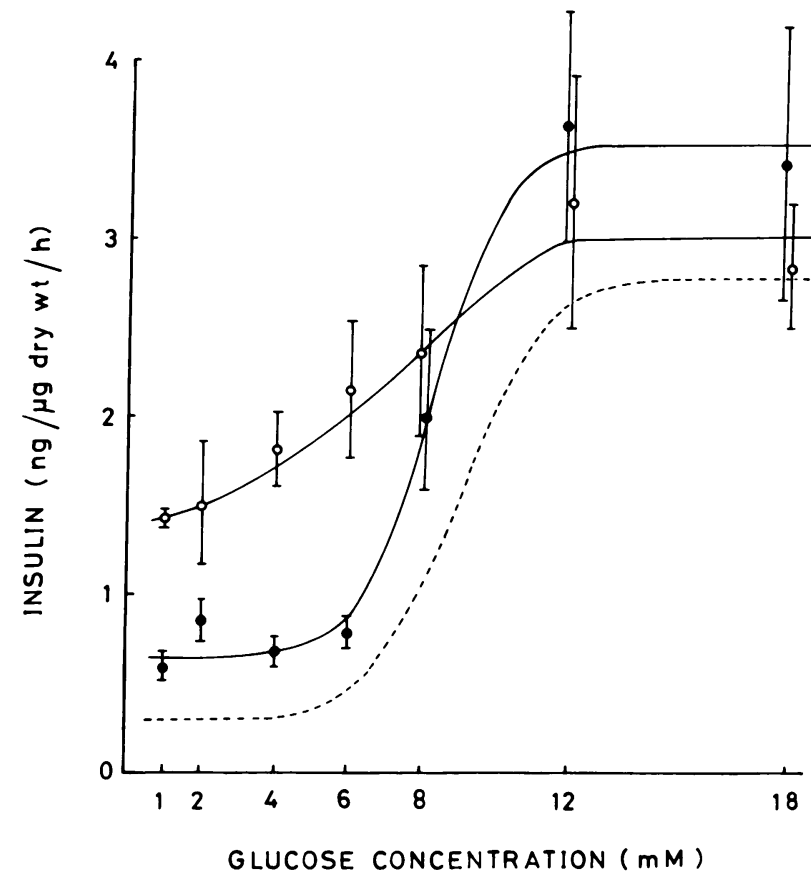

Figure 1 Dose-response relationships for glucose-stimulated insulin release. Glucose-stimulated insulin release was measured during incubation in 1-18 mM glucose media from batches of two islets stored for 1 wk at $8^{\circ} \mathrm{C}$, recovered, and preincubated (- -) and from fresh, unstored islets exposed to the same recovery, preincubation, and incubation periods (-O-). Data are also given for fresh islets exposed only to a $1-\mathrm{h}$ preincubation and then incubated as above (-- , from Buitrago et al., ref. 1). Insulin release is given as mean $\pm S E M$ for $7-10,6-7$, and $4-7$ experiments, respectively. 
TABLE III

Insulin Release into the Storage Medium and Islet Content of Insulin after Storage for 1 wk

\begin{tabular}{|c|c|c|c|c|}
\hline $\begin{array}{c}\text { Storage } \\
\text { temperature }\end{array}$ & $\begin{array}{c}\text { Glucose } \\
\text { concen- } \\
\text { tration } \\
\text { in the } \\
\text { storage } \\
\text { medium }\end{array}$ & $\begin{array}{l}\text { Insulin } \\
\text { release } \\
\text { into the } \\
\text { storage } \\
\text { medium* }\end{array}$ & $\begin{array}{l}\text { Insulin } \\
\text { content } \\
\text { of the } \\
\text { islets*t }\end{array}$ & $\begin{array}{l}\text { Sum of } \\
\text { insulin } \\
\text { release } \\
\text { into the } \\
\text { storage } \\
\text { medium } \\
\text { and insulin } \\
\text { content of } \\
\text { the islets } * 8\end{array}$ \\
\hline${ }^{\circ} \mathrm{C}$ & $m M$ & $\begin{array}{l}n g / \mu g d r y \\
w t / 7 \text { days }\end{array}$ & $\begin{array}{l}n g / \mu g \\
d r y w t\end{array}$ & $\begin{array}{l}n g / \mu g \\
d r y w t\end{array}$ \\
\hline 37 & 18 & $\begin{array}{c}222.5 \pm 20.6 \\
(26)\end{array}$ & $\begin{array}{c}133.7 \pm 7.1 \\
(14)\end{array}$ & $\begin{array}{c}331.7 \pm 20.8 \\
(14)\end{array}$ \\
\hline 22 & 18 & $\begin{array}{c}36.8 \pm 3.9 \\
(24)\end{array}$ & $\begin{array}{c}174.7 \pm 10.6 \\
(16)\end{array}$ & $\begin{array}{c}218.3 \pm 16.0 \\
(16)\end{array}$ \\
\hline 8 & 18 & $\begin{array}{c}20.3 \pm 1.0 \\
(88)\end{array}$ & $\begin{array}{c}228.6 \pm 15.7 \\
(18)\end{array}$ & $\begin{array}{c}250.7 \pm 16.8 \\
(17)\end{array}$ \\
\hline 37 & 3 & $\begin{array}{c}54.1 \pm 3.5 \\
(24)\end{array}$ & $\begin{array}{c}87.1 \pm 7.4 \\
(23)\end{array}$ & $\begin{array}{c}145.5 \pm 6.6 \\
(23)\end{array}$ \\
\hline 8 & 3 & $\begin{array}{c}21.3 \pm 2.3 \\
(2.3)\end{array}$ & $\begin{array}{c}184.5 \pm 13.1 \\
(24)\end{array}$ & $\begin{array}{c}219.5 \pm 24.1 \\
(23)\end{array}$ \\
\hline $\begin{array}{l}\text { Fresh } \\
\text { islets }\end{array}$ & & & $\begin{array}{c}190.2 \pm 11.1 \\
(20)\end{array}$ & \\
\hline
\end{tabular}

* Mean \pm SEM for the number of experiments listed in parentheses. $\ddagger$ Measured after recovery, preincubation, and incubation.

The sum of release during storage and content after incubation is shown for comparison with the content of fresh islets after identical recovery preincubation, and incubation. without weekly incubation), did not result in a significant reduction of islet insulin content.

\section{DISCUSSION}

In the present study the term "storage" rather than "culture" of pancreatic islets has been used to emphasize that our aim was to develop a technique for maintaining adult islets functionally intact. Although storage in the $4-10^{\circ} \mathrm{C}$ range has been used for isolated fibroblasts (8) and many other tissues (3-6), Knight et al. (9) were unsuccessful in maintaining insulin release from pancreatic islets stored at $4^{\circ} \mathrm{C}$ with $5.6 \mathrm{mM}$ glucose for 4 days. The present success may be because the glucose concentration in the storage medium was as high as $18 \mathrm{mM}$, since no glucose-stimulated insulin release remained after storage with only $3 \mathrm{mM}$ glucose at $8^{\circ} \mathrm{C}$. The relatively complex $\mathrm{TCM} 199$, rather than only Hanks' balanced salt solution, may have provided some necessary nutritional requirement. In addition, hand-dissection instead of collagenase isolation, which may damage the islets during long-term storage in the absence of serum (1), or the use of $8^{\circ}$ instead of $4^{\circ} \mathrm{C}$, may have been of importance.

The present studies confirm the findings of other authors $(1,14)$ that storage in high-glucose media for $1 \mathrm{wk}$ at $37^{\circ} \mathrm{C}$ is associated with synthesis and release of

TABLE IV

Insulin Release during Storage and Incubation, and Islet Content of Insulin after Storage for 1-5 wk at $8^{\circ} \mathrm{C}$ with $18 \mathrm{mM}$ Glucose

\begin{tabular}{|c|c|c|c|c|c|}
\hline & \multirow{2}{*}{$\begin{array}{l}\text { Insulin release into } \\
\text { the storage medium* }\end{array}$} & \multicolumn{3}{|c|}{ Insulin release during incubation* } & \multirow{2}{*}{$\begin{array}{c}\text { Islet content o } \\
\text { insulin* }\end{array}$} \\
\hline & & $1 \mathrm{mM}$ & $18 \mathrm{mM}$ & Difference & \\
\hline & $n g / \mu g d r y w t$ & \multicolumn{3}{|c|}{$n g / \mu g d r y w t / h$} & $n g / \mu g d r y w t$ \\
\hline \multicolumn{6}{|c|}{ Islets incubated weekly } \\
\hline wk 1 & $\begin{array}{c}14.88 \pm 1.39 \\
(20)\end{array}$ & $\begin{array}{c}0.83 \pm 0.15 \\
(10)\end{array}$ & $\begin{array}{c}3.18 \pm 0.39 \\
(10)\end{array}$ & $\begin{array}{l}2.36 \pm 0.52 \ddagger \\
(10)\end{array}$ & \\
\hline wk 2 & $\begin{array}{l}5.46 \pm 0.65 \\
(20)\end{array}$ & $\begin{array}{c}0.19 \pm 0.03 \\
\quad(10)\end{array}$ & $\begin{array}{c}1.75 \pm 0.26 \\
(10)\end{array}$ & $\begin{array}{l}1.56 \pm 0.268 \\
(10)\end{array}$ & \\
\hline wk 3 & $\begin{array}{l}2.43 \pm 0.23 \\
\quad(20)\end{array}$ & $\begin{array}{l}0.18 \pm 0.02 \\
\quad(10)\end{array}$ & $\begin{array}{l}3.35 \pm 0.76 \\
\quad(10)\end{array}$ & $\begin{array}{l}3.18 \pm 0.76 \ddagger \\
\quad(10)\end{array}$ & \\
\hline wk 4 & $\begin{array}{l}1.92 \pm 0.16 \\
(20)\end{array}$ & $\begin{array}{l}0.24 \pm 0.07 \\
\quad(10\end{array}$ & $\begin{array}{c}1.24 \pm 0.26 \\
(10)\end{array}$ & $\begin{array}{l}1.01 \pm 0.25 \ddagger \\
(10)\end{array}$ & \\
\hline wk 5 & $\begin{array}{l}2.14 \pm 0.38 \\
\quad(14)\end{array}$ & $\begin{array}{c}0.19 \pm 0.03 \\
(7)\end{array}$ & $\begin{array}{c}1.17 \pm 0.21 \\
(7)\end{array}$ & $\begin{array}{l}0.98 \pm 0.20 \ddagger \\
\quad(7)\end{array}$ & $\begin{array}{c}157.2 \pm 16.0 \\
(15)\end{array}$ \\
\hline \multicolumn{6}{|c|}{ Islets in continuous cold $\|$} \\
\hline 3 wk & $\begin{array}{c}20.63 \pm 2.09 \\
(10)\end{array}$ & $\begin{array}{c}0.71 \pm 0.08 \\
(5)\end{array}$ & $\begin{array}{c}0.36 \pm 0.12 \\
(5)\end{array}$ & $\begin{array}{c}-0.35 \pm 0.17 \\
(5)\end{array}$ & $\begin{array}{c}206.8 \pm 15.7 \\
(10)\end{array}$ \\
\hline 5 wk & $\begin{array}{c}32.10 \pm 3.15 \\
(8)\end{array}$ & $\begin{array}{c}0.42 \pm 0.07 \\
(4)\end{array}$ & $\begin{array}{c}0.23 \pm 0.03 \\
(4)\end{array}$ & $\begin{array}{c}-0.18 \pm 0.08 \\
(4)\end{array}$ & $\begin{array}{c}246.6 \pm 20.7 \\
(9)\end{array}$ \\
\hline
\end{tabular}

* Mean \pm SEM for the number of experiments listed in parentheses.

$\ddagger P<0.005$.

$\S P<0.001$.

|| Recovery, preincubation, and incubation only on the 3rd or 5th wk. 
insulin during this period, and with a fall of islet insulin content. We also confirm (1) that storage at $37^{\circ} \mathrm{C}$ in a high-glucose medium maintains a greater insulin response to glucose than storage in a low-glucose medium. Although one would expect ATP-producing and -requiring metabolic processes to have nearly ceased at low temperatures, it is evident that a high glucose concentration is essential for preservation of insulin secretion during storage at $8^{\circ} \mathrm{C}$ as well. Since a small but significant amount of glucose utilization has been found in kidney cortex slices stored at $10^{\circ} \mathrm{C}(15)$, it is possible that some glucose metabolism in the islets continues at $8^{\circ} \mathrm{C}$ and is important for the maintenance of glucosestimulated insulin release. An alternative explanation is that the glucose molecule as such protects the secretory machinery in some way.

Transfer of $37^{\circ} \mathrm{C}$-stored islets from the storage medium containing $18 \mathrm{mM}$ glucose directly to the preincubation medium wtih only $1 \mathrm{mM}$ glucose suppressed insulin release within $30 \mathrm{~min}$, as would be expected. Despite the fall in glucose concentration, the cold-stored islets required up to $60 \mathrm{~min}$ to reach basal insulin release. Glucose-stimulated insulin release during the subsequent incubation was only $20-25 \%$ of that of fresh islets. Although basal insulin release had been achieved, it is possible that the low concentration of glucose during the preincubation had not allowed proper restoration of the intra- $\beta$-cell milieu, since intracellular metabolism had probably been altered during the cold storage (16). Therefore, a 4-h period with $18 \mathrm{mM}$ glucose at $37^{\circ} \mathrm{C}$ was added between the storage and the preincubation in an attempt to allow the islets to recover. The addition of this recovery period restored insulin release from the $8^{\circ} \mathrm{C}$-stored islets to fresh-islet levels. In fact, glucosestimulated insulin release throughout the 1-18 mM glucose range was strikingly parallel to that of fresh islets. However, the appropriate control, fresh islets subjected to the same recovery period, exhibited increased basal release of insulin but no significant change in maximal release. This observation is in accordance with Hoshi and Shreeve (17) and unpublished data from our laboratory indicating that perifusion of pancreatic islets for 4-12 $\mathrm{h}$ caused increased basal release of insulin. When islets were stored for more than 1 wk at $8^{\circ} \mathrm{C}$, it was obvious that a weekly recovery period was necessary for maintenance of insulin release. This procedure delayed but did not completely prevent loss of glucosestimulated insulin release, which after 5 wk corresponded to the release from islets stored for 1 wk at $37^{\circ} \mathrm{C}$.

From the present data, it is obvious that storage in the cold prevents loss of islet insulin. The high insulin content of the cold-stored islets might be a factor in the maintenance of insulin release. However, it is not the only factor, since islets stored at $8^{\circ} \mathrm{C}$ for $1 \mathrm{wk}$ with only
$3 \mathrm{mM}$ glucose or continuously for 3 or 5 wk with 18 $\mathrm{mM}$ glucose did not lose significant amounts of insulin, although they did lose the ability to release insulin in response to glucose.

The present studies indicate that glucose-stimulated insulin release from isolated $o b / o b$ mouse pancreatic islets is fully maintained by storage for $1 \mathrm{wk}$ at $8^{\circ} \mathrm{C}$ followed by warming to $37^{\circ} \mathrm{C}$ in a tissue culture medium containing a high concentration of glucose. During longer periods, a significant response is maintained if the islets are warmed once a week. Assuming that glucose-stimulated insulin release in vitro reflects an islet's future ability to relieve diabetic symptoms when transplanted, these studies strongly recommend the present technique for storage of islets for transplantation. Apart from the reservation one has to make when applying results obtained from experiments with animals to humans, these studies suggest a technique for keeping donor islets functionally intact for long periods of time -a significant factor, since present techniques for isolation of human islets are difficult and give variable results (18).

\section{ACKNOWLEDGMENTS}

The authors gratefully acknowledge the excellent technical assistance of Ms. Gerd Larsson and Mr. Gunnar Bäckman.

This work was supported by the Swedish Medical Research Council (12x-562) and the Swedish Diabetes Association.

\section{REFERENCES}

1. Buitrago, A., E. Gylfe, B. Hellman, L.-Å. Idahl, and M. Johansson. 1975. Function of microdissected pancreatic islets cultured in a chemically defined medium. I. Insulin content and release. Diabetologia. 11.

2. Andersson, A. 1974. Long-term effects of glucose on insulin release and glucose oxidation by mouse pancreatic islets maintained in tissue culture. Biochem. $J$. 140: 377-382.

3. Belzer, F. O. 1974. Current concepts. Renal preservation. N. Engl. J. Med. 291: 402-404.

4. Bĕhounková, E. 1971. Histologic examination of skin grafts stored at $+4^{\circ} \mathrm{C}$. Acta Chir. Plast. 13: 128-132.

5. Veith, F. J., and S. K. Koerner. 1974. The present status of lung transplantation. Arch. Surg. 109: 734-740.

6. Durst, A. L. 1973. The present status of liver transplantation. Isr. J. Med. Sci. 9: 98-101.

7. Kostianovsky, M., P. E. Lacy, M. H. Greider, and M. F. Still. 1972. Long term (15 days) incubation of islets of Langerhans isolated from adult rats and mice. Lab. Invest. $27: 53-61$.

8. Matsumura, T., T. Takaoka, and H. Katsuta. 1973. Survival of cultured cells in the cold. A kinetic study with special reference to the effect of serum in culture media. Exp. Cell Res. 76: 297-304.

9. Knight, M. J., D. W. Scharp, C. B. Kemp, W. F. Ballinger, and P. E. Lacy. 1973. Effects of cold storage on the function of isolated pancreatic islets. Cryobiology. $10: 89-90$.

10. Salk, J. E., J. S. Youngner, and E. N. Ward. 1954. Use of color change of phenol red as the indicator in titrating

Cold Storage of Pancreatic Islets 
poliomyelitis virus or its antibody in a tissue-culture system. Appendix. Method of preparing mixture 199. Am. J. Hyg. 60: 225-230.

11. Hellman, B. 1965. Studies in obese-hyperglycemic mice. Ann. N. Y. Acad. Sci. 131: 541-558.

12. Hellerström, C. 1964. A method for the microdissection of intact pancreatic islets of mammals. Acta Endocrinol. 45: 122-132.

13. Lowry, O. H. 1953. The quantitative histochemistry of the brain. Histological sampling. J. Histochem. Cytochem. $1: 420-428$.

14. Andersson, A., J. Westman, and C. Hellerström. 1974. Effects of glucose on the ultrastructure and insulin biosynthesis of isolated mouse pancreatic islets maintained in tissue culture. Diabetologia. 10: 743-753.

15. Huang, J. S., G. L. Downes, G. L. Childress, J. M. Felts, and F. O. Belzer. 1974. Oxidation of ${ }^{14} \mathrm{C}$-labeled substrates by dog kidney cortex at 10 and $38^{\circ} \mathrm{C}$. Cryobiology. 11 : 387-394.

16. Dragomir, C. T., and E. Pausescu. 1974. Theoretical considerations regarding the cell membrane function during cold-induced preservation of tissues and organs: new possibilities for optimizing the process. J. Theor. Biol. 47 : 281-293.

17. Hoshi, M., and W. W. Shreeve. 1973. Release and production of insulin by isolated, perifused rat pancreatic islets. Control by glucose. Diabetes. 22: 16-24.

18. Hellerström, C., A. Andersson, C. G. Groth, R. Gunnarsson, G. Lundgren, J. Westman, and J. Östman. 1975. Structure and metabolism of human pancreatic islets maintained in tissue culture. Diabetologia. 11: 348. (Abstr.) 